\title{
The Effect of the Photoperiod and Exogenous Melatonin on the Protein Content in Sheep Milk
}

\author{
Edyta Molik, Genowefa Bonczar, Tomasz Misztal, \\ Aneta Żebrowska and Dorota Zięba
}

Additional information is available at the end of the chapter

http://dx.doi.org/10.5772/46101

\section{Introduction}

The first product of mammary gland in mammals is colostrum, which differs from milk with respect to density, colour and reaction, and is mildly acidic ( $\mathrm{pH}$ of 6.4). Protein substances in colostrum account for approximately $60 \%$ of the dry matter, including more than $80 \%$ whey protein and almost $20 \%$ casein protein. Colostrum contains 19 exogenous aminoacids. Specifically, colostrum casein and phosphates form a complex of macromolecular micelles that contains a number of exogenous aminoacids (valine, leucine, proline, and lysine), and whey proteins found in the colostrum in the form of a colloid have a high content of cystine, cysteine and lysine [1]. Milk, the product of the mammary gland of mammals, is the first food of a young mammal, and its composition fully reflects the nutritional needs of the organism. The diverse composition of milk in different animal species results from the specific nutritional and physiological needs of the young. Thus, great importance is attached to the level of the components, such as protein, fat, lactose, and mineral salts, which are likely to change due to a number of factors [2,3].

\section{Characterisation of nitrogen compounds in ruminant milk}

Protein is one of the more important components of sheep milk and represents $95 \%$ of all nitrogen compounds (total nitrogen). The remaining $5 \%$ of nitrogen compounds form non protein nitrogen compounds [2,4]. Milk proteins represent a heterogeneous group of compounds, which differ with respect to their composition and properties. The protein content in sheep milk is diverse and varies from $4.75 \%$ to $7.2 \%$, which is attributable to a variety factors, including the breed, lactation period, health of the udder, diet, age, number of fed lambs and climate conditions $[2,4,5,6]$. Numerous studies have shown that the diverse protein content of milk is connected with the breed of the sheep that the milk was obtained. 
Another factor affecting the content of the milk is the lactation period. The level of protein in colostrum generated within the first hours after lambing can be as high as $19.5 \%$ [4]. The protein content in sheep milk in subsequent lactation weeks gradually increases and reaches a maximum level in the last week [3]. Ramos and Juarez [4] report that the protein content in sheep milk at the end of lactation can be higher than $6.8-8.9 \%$. The studies by Bonczar [7] reveal that subclinical mastitis causes an increase in the protein content. However, Novotna et al. [8] concluded that the protein level in milk containing more than 200,000 somatic cells per $1 \mathrm{ml}$ is significantly lower compared to milk with a low number of cells. Proteins in sheep milk are diverse with respect to the molecular weight, amino-acid composition, structure and properties, which constitutes a base to distinguish two groups of proteins: caseins and whey proteins.

\section{Characterisation of casein and whey proteins in ruminant milk}

Sheep milk, like milk from other ruminants, belongs to casein milk, which is milk with a high casein content compared to the level of total nitrogen compounds, as opposed to mare milk or human milk, which contains less casein and more whey protein (shown in Table 1).

\begin{tabular}{ccccc}
\hline Species & Protein (\%) & Casein (\%) & Whey proteins (\%) & $\begin{array}{c}\text { Share of casein in the total } \\
\text { protein content (\%) }\end{array}$ \\
\hline Human & 1.1 & 0.4 & 0.7 & 36.3 \\
Cattle & 3.4 & 2.8 & 0.6 & 78.1 \\
Buffalo & 4.8 & 4.2 & 0.6 & 87.5 \\
Goat & 2.9 & 2.5 & 0.4 & 80.6 \\
Sheep & 5.5 & 4.6 & 0.9 & 83.6 \\
Horse & 2.0 & 1.3 & 0.7 & 65.0 \\
Reindeer & 10.2 & 8.5 & 1.7 & 83.3 \\
Camel & 3.3 & 2.9 & 0.4 & 87.9 \\
\hline
\end{tabular}

Table 1. The content of protein, casein and whey proteins in human milk and milk of various animal species adapted from $[39,40]$

From a chemical point of view, casein, which is the most important milk protein, is a phosphoprotein that accounts for $75-83.8 \%$ of all nitrogen compounds in sheep milk [4]. Casein is not a homogeneous protein and is composed of four fractions: $\alpha$ s-casein $(48.5 \%)$, $\beta$-casein $(38.1 \%), \kappa$-casein $(13.4 \%)$ and $\gamma$-casein $(5 \%)$. The casein content in ruminants, which is higher than cow milk, determines the high production efficiency of the material. The major fraction of casein in milk from small ruminants is $\beta$-casein, which contains approximately $55 \%$ of the total nitrogen content, whereas casein represents only $36 \%$ of the nitrogen content in cow milk. In casein from small ruminants, it is possible to observe a high concentration of the $\alpha \mathrm{s} 2$ fraction (10-30\%), whereas in cow casein, it only accounts for $12 \%$. The content of $\kappa$-casein in goat and sheep milk is $20 \%$ on average, and this value is greater than cow milk, which is only $14 \%$ (Table 2.) $[9,10]$. 


\begin{tabular}{|c|c|c|c|c|c|c|c|}
\hline \multirow{3}{*}{ Components } & \multicolumn{7}{|c|}{ Milk } \\
\hline & \multicolumn{2}{|c|}{ Cow } & \multicolumn{2}{|c|}{ Sheep } & \multicolumn{2}{|c|}{ Goat } & \multirow{2}{*}{$\begin{array}{c}\text { Huma } \\
\mathrm{n}\end{array}$} \\
\hline & $\bar{x}$ & $S(E)$ & $\bar{x}$ & $S(E)$ & $\bar{x}$ & $S(E)$ & \\
\hline Water & 87.3 & $85.8-88.8$ & 80.6 & $75.7-86.1$ & 86.6 & $79.9-89.3$ & 87.2 \\
\hline Dry matter & 12.7 & $11.2-14.5$ & 19.4 & $13.9-24.3$ & 13.4 & $10.7-20.1$ & 12.8 \\
\hline Proteins, including: & 3.2 & $3.05-3.85$ & 5.6 & $4.47-6.83$ & 3.9 & $2.8-5.0$ & 1.2 \\
\hline Casein & 2.5 & $2.0-3.0$ & 4.2 & $4.17-4.3$ & 2.7 & $2.3-3.2$ & 0.5 \\
\hline Whey proteins & 0.6 & $0.5-0.8$ & 1.1 & $0.9-1.3$ & 0.6 & 0.4-0.7 & 0.7 \\
\hline
\end{tabular}

Table 2. Comparison of the chemical composition of cow's milk, sheep milk, goat milk and human milk $(\mathrm{g} / 100 \mathrm{~g})$ adapted from [41]

As in proteins, the casein content is variable, which is caused by different factors, including the sheep breed, lactation period, and health of the udder [5,11]. In the milk of different sheep breeds, the level of casein may vary from $4.4 \%$ to $5.3 \%$. The lowest level of casein is found in the colostrum (21-50\% of the total protein content). It was also reported that the level of casein in the milk from udders with mastitis was lower than in milk from healthy udders. Caseins form spherical micelles with a diameter that ranges from $80 \mathrm{~nm}$ to $190 \mathrm{~nm}$ and forms a colloidal solution [2,5]. Caseins are produced in the milk-producing cells of the udder. Bonczar and Paciorek [2] reported that casein micelles in sheep milk are richer in $\mathrm{Ca}$ compared to micelles in cow milk, and no $\mathrm{CaCl}_{2}$ additive is required in the production of sheep cheese. Casein micelles are composed of the following fractions: $\alpha_{\mathrm{s} 1 \text {-casein }}$ with 5 genetic variants $(\mathrm{A}, \mathrm{B}, \mathrm{C}, \mathrm{D}$, and $\mathrm{E}), \alpha_{\mathrm{s} 2}$-casein with 3 genetic variants $(\mathrm{A}, \mathrm{B}$, and $\mathrm{F}), \beta$-casein with 3 genetic variants $(A, B$, and $C)$ and $\kappa$-casein, which has no known genetic variants $[4,12]$. The share of the $\alpha_{\mathrm{s}}$-casein fraction compared to the total casein content ranges from $47.2-56.5 \%$, and the share of $\beta$-casein ranges from $28.1-36.0 \%$ while the share of $\kappa$-casein ranges from 10.6-12.1\% [5]. The amino-acid composition of casein is diverse, and glutamic acid is the most dominant aminoacid; however, some authors have varying opinions on the contents of proline and sulphur-containing aminoacids. Some studies have suggested that sheep milk does not contain these aminoacids at all, whereas other studies have shown that their level is relatively high $[5,13]$. Casein micelles are particularly abundant in calcium and colloidal phosphorus and contains approximately 53.14 (Ca) and 22.99 (P) mM/l in sheep milk, respectively, which is why there is no need to add calcium to the milk after pasteurisation in cheese production [5]. Casein undergoes a coagulation process induced by rennet, which is used in the production of cheeses made with rennet. The process can also cause the acidification of milk to its isoelectric point ( $\mathrm{pH}$ of 4.6 at the temperature of $20^{\circ} \mathrm{C}$ ).

Whey proteins are the second basic group of proteins, which includes mostly albumins represented in milk by three major fractions: $\beta$-lactoglobulin, $\alpha$-lactalbumin and serum albumin. The major fractions in whey proteins are $\beta$-lactoglobulins $(67 \%)$, immunoglobulins $(20 \%)$, and the remaining fractions contain $\alpha$-lactalbumins and serum albumin. The proteins are found in milk, and they are difficult to isolate as their coagulum is fine and easily dispersed. Unlike casein, the proteins do not contain phosphorus; however, they include a 
considerable amount of cystine, cysteine and lysine [14]. The major fraction in whey proteins is $\beta$-lactoglobulin, followed by immunoglobulins, $\alpha$-lactalbumin and serum albumin. Sheep milk has a high level of aminoacids compared to cow milk, particularly lysine, valine and serine, which have a favourable effect on the human organism $[5,15]$. The content of whey protein in milk is approximately $0.6 \%$, which accounts for $20 \%$ of the nitrogen content. The proteins do not include phosphate residues; however, they contain a high content of sulpher-containing aminoacids. Unlike typical albumins, $\beta$-lactoglobulin, which represents approximately $50 \%$ of whey proteins, is not water-soluble; however, it is relatively easy to dissolve in dilute solutions of natural salts. $\alpha$-Lactoalbumin and blood serum albumin are typical water-soluble albumin proteins. These proteins are more resistant to thermal denaturation compared to $\beta$-lactoglobulin. Compared to cow milk, whey proteins from sheep milk are more sensitive to heating. Pasteurisation of sheep milk at $65^{\circ} \mathrm{C}$ for 30 minutes causes denaturation of approximately $15 \%$ of the water-soluble proteins, whereas only $2.3 \%$ of cow milk proteins are denatured under these conditions. $\beta$-Lactoglobulin found in whey protein binds to heavy metals during heating, such as copper and iron, which prevents oxidation to the fat by the metals and significantly increases the shelf life of dairy products. A complex with iron is durable even after thermal denaturation. It has been shown that lactoferrin from sheep milk destroys Micrococcus flavusto a greater extent than cow lactoferrin [16]. Immunoglobulins, which account for approximately $10 \%$ of whey protein, are a mixture of high-molecular proteins with immunological properties and are composed of aminoacids and saccharides. We can distinguish three types corresponding to blood $\gamma$ globulins: $\mathrm{G}$ immunoglobulins (IgG), A immunoglobulins (IgA) and $\mathrm{M}$ immunoglobulins $(\operatorname{IgM})$, which differ with respect to molecular weight and saccharide content. Despite the fact that the amino-acid composition and sequences of $\beta$-lactoglobulin and $\alpha$-lactalbumin are known, not all of their biological functions have been determined, and $\alpha$-lactalbumin, which is a regulatory protein, supports the binding of glucose to UDP-galactose [17].

\section{Nutritional value of sheep milk proteins}

Sheep milk is believed to have a high nutritional value compared to milk from other species of mammals, and it has a richer chemical composition. Clare and Swaisgood [18] stated that the compounds function in a number of biological functions in the human body, such as digestion, hormonal activity, immunity, neurology and nutrition. The most important peptides with strong biological properties include casokinines, lactorphines, casein phosphopeptides, casoxines and lactoferroxines. Due to the biological activity of these peptides, they can be used in the pharmaceutical industry in drug production and in the food industry in the production of dietary supplements. The antibacterial properties of peptides, such as those of casecidin, casocidin, isracidin, lactoferricin and lactoferrin, make it possible to use peptides as food additives to ensure its health safety [19]. The nutritional value of sheep milk results from the high content of components that are valuable to the human body as exogenous aminoacids, such as short-chain and medium-chain fatty acids, which may play an important role in the treatment of patients with metabolic disorders and in people suffering from hypercholesterolaemia [5,15]. Table 3. 


\begin{tabular}{ccc}
\hline Amino-acids & In $\mathrm{g} / 100 \mathrm{~g}$ of sheep milk & In $\mathrm{g} / 100 \mathrm{~g}$ of casein \\
\hline Tryptophan & 0.084 & 1.3 \\
Threonine & 0.268 & 3.6 \\
Isoleucine & 0.338 & 5.1 \\
Leucine & 0.587 & 9.0 \\
Lysine & 0.513 & 7.3 \\
Methionine & 0.155 & 2.1 \\
Cystine & 0.035 & 0.8 \\
Phenyloalanine & 0.284 & 5.2 \\
Tyrosine & 0.281 & 5.6 \\
Valine & 0.448 & 6.7 \\
Arginine & 0.198 & 3.3 \\
Histidine & 0.167 & 3.3 \\
Alanine & 0.269 & 3.2 \\
Aspartic acid & 0.328 & 7.7 \\
Glutamic acid & 1.019 & 21.1 \\
Glycine & 0.041 & 1.7 \\
Proline & - & 10 \\
Serine & 0.492 & 5.0 \\
\hline
\end{tabular}

Table 3. Amino-acid composition of sheep milk proteins adapted from $[5,15]$

\begin{tabular}{cccccc}
\hline & $\begin{array}{c}\text { Recommended } \\
\text { daily } \\
\text { Specification } \\
\text { allowances for } \\
\text { an adult } \\
\text { individual }\end{array}$ & $\begin{array}{c}\text { Content in a } \\
\text { glass of } \\
\text { milk }\end{array}$ & $\begin{array}{c}\text { Satisfaction of } \\
\text { recommended } \\
\text { daily allowances } \\
(\%)\end{array}$ & $\begin{array}{c}\text { Sheep milk } \\
\text { Content in a a } \\
\text { glass of milk }\end{array}$ & $\begin{array}{c}\text { Satiocom of } \\
\text { reconded } \\
\text { daily } \\
\text { allowances (\%) }\end{array}$ \\
\hline Energy [kJ] & 10870 & 643 & 5.9 & 1128 & 10.4 \\
Protein [g] & 75 & 8.2 & 11.0 & 15 & 20 \\
Fat [g] & 100 & 8.8 & 8.8 & 17.5 & 17.5 \\
Carbohydrates [g] & 400 & 11.3 & 2.8 & 11.3 & 2.8 \\
Calcium [mg] & 800 & 300 & 37.5 & 483 & 60.3 \\
Phosphorus [mg] & 800 & 233 & 29.1 & 395 & 49.4 \\
Iron [mg] & 12 & 0.13 & 1.1 & 0.25 & 2.1 \\
Magnesium [mg] & 350 & 32.5 & 9.3 & 45 & 12.9 \\
Vitamin C [mg] & 75 & 2.4 & 3.2 & 10.4 & 13.9 \\
Vitamin B & 1.4 & 0.10 & 7.1 & 0.16 & 11.4 \\
Witamin B & 1.4 & 0.41 & 29.3 & 0.89 & 63.6 \\
\hline
\end{tabular}

Table 4. Relative contributions of cow and sheep milks to recommended daily allowances for nutrients and energy, adapted from [20] 
The amino-acid content in sheep milk is proportionally higher than in cow milk because sheep milk contains a higher level of serine, alanine, histidine, valine and lysine, whereas the content of cystine and glycine is lower [13]. The high nutritional value of sheep milk is also related to the proline content, which affects the production of haemoglobin, and the high cytological quality is determined by a relatively low content of somatic cells in the milk, which is approximately 200 cells $/ \mathrm{cm}^{3}$. The nutritional value of milk is appropriately illustrated by the degree to which the recommended daily allowance of an individual adult for nutrients and energy is met by drinking a glass of the milk. As it was reported by Haenlein [15], drinking two glasses of sheep milk (1/2 litre), or consumption of an equivalent portion of sheep yogurt or cheese, satisfies $162 \%$ of the recommended dietary allowance (RDA) of protein for an adult, 121\% of the RDA for calcium and $200 \%$ of the RDA for riboflavin. Although two glasses of sheep milk is not enough to satisfy the allowances for all substances and energy, it meets the requirements better than cow milk (Table 4) [20]. One litre of sheep milk contains $900-1050 \mathrm{kcal}$, whereas the same amount of cow milk delivers only $700 \mathrm{kcal}$ [21]. Table 4

\section{Modulation of the protein content in the milk of seasonally breeding sheep}

There is increased interest in products made from sheep milk because of the high content of components that are valuable for humans, and there is a need to deliver this product to the market throughout the year [5,22]. However, due to specific characteristics of the reproduction cycle in seasonally breeding sheep, the lactation period is from the time of lengthening days to the end of September, which does not allow for obtaining sheep milk and its products throughout the entirety of the year. Therefore, studies have been performed over the past several years with the goal of determining the role of day length and exogenous melatonin in the modulation of milk yields and chemical composition of milk in seasonally breeding sheep. It is well known that light influences the behaviour of animals. As early as 1925, Rowan [23] showed that lighting conditions have an effect on gonad activity in birds, and the processes connected with them are controlled by intraorganic signals. In farm animals, changes in day length play an important role in determining their yields. Introduction of a long photoperiod in cows produced an increase in the prolactin content and overall milk yield [24].

The photoperiod is of special importance to short-day animals (sheep) where the day length is related with changes in melatonin concentrations [25]. In sheep, changes in day length are perceived as a biological marker with respect to reproductive function and impact the processes of milk secretion and lactation. The major gland that acts as a messenger to transmit information from the external environment to the central regulating activities of the organism, which informs the organism of season changes, is the pineal gland, which is where melatonin is synthesised [26]. The biosynthesis of melatonin in most animals is dependent on the lighting conditions. The highest concentration of the hormone known as the "hormone of darkness" is at night [27-29]. It is typical for the circadian rhythm of 
melatonin secretion to increase its concentration in the dark phase and drop during the day, and this process occurs in all animals. Seasonal changes in melatonin secretion result from the activity of the biological clock, which sends a signal in the annual reproduction cycle in animals characterised by seasonal reproduction.

The endocrine mechanism of entering and maintaining lactation is not fully understood. However, it is clear that this process involves a number of hormones, which shows that the process relies on the activity of the hypothalamus and pituitary gland [30]. Currently, it is believed that milk yields in mammals are determined by genetic and environmental factors [31]. However, in recent years, more attention has been paid to the role of light, which is a factor that modulates the concentration of prolactin and depends on the annual rhythm of melatonin concentrations. In natural conditions, the maximum concentration of prolactin in the blood is identified in the long-day period, and at this time, the level of melatonin decreases. The lowest concentration of prolactin is observed during the short-day period, which is when the level of melatonin is the highest [32,33]. Experiments performed by Molik et al. $[34,35]$ demonstrated that day length likely determines the milk yield of sheep. Sheep entering lactation in the short-day period had a milk yield of $50 \%$ compared to sheep milked in the long-day period. Changes in the secretion of prolactin during the lactation period of sheep have an effect on the amount of milk produced and on the synthesis of proteins, fat and immunoglobulins, which indicates that they determine its composition, quality and technological usability. The knowledge of physiological and endocrinological mechanisms that determine the lactation level may contribute to a better understanding of the relationship between the photoperiod and milk yields in sheep [36]. If the season determines the amount of milk produced, it can be presumed that it also modulates the chemical composition and nutritional value of products made from the milk.

\section{The effect of a diverse photoperiod and exogenous melatonin on the protein and casein contents in sheep milk produced during the long-day period}

A change in the day length is a vital factor that affects the yields of seasonally breeding farm animals. Therefore, the purpose of these experiments was to determine the effects of day length and exogenous melatonin on the protein and casein contents in sheep entering lactation in the long-day period. The experiments were performed on 60 Polish long-wool sheep mothers that were bred with a seasonal reproduction cycle, aged 4-5 years and weighed $60 \pm 5 \mathrm{~kg}$. Synchronisation of the sheep estrous cycle was performed with gestagens using the Chronogest ${ }^{\circledR}$ method. Polyurethane foams saturated with $40 \mathrm{mg}$ of the cronolone preparation (Intervet; Holland) were inserted into the sheep vaginally for the period of 14 days. When the foam pads were removed, the ewes were administered 500 IU of PMSG (Serogonadotropin; Biowet, Drwalew). Estrous ensued 48-72 hours after administering the preparation, and its duration was controlled with a teaser ram. The breeding season for all groups of sheep occurred from the $15^{\text {th }}$ to the $30^{\text {th }}$ of September, whereas lambing ensued in the second half of February. Lambs were raised with mothers before being separated, and 
the mothers were milked. After separation of lambs on the $57^{\text {th }}$ day of lactation, the sheep were divided into three groups: Group 1 ( $n=20$ sheep, sheep from the control group maintained in natural day-length conditions), Group 2 ( $\mathrm{n}=20$ sheep, sheep with subcutaneous melatonin implants that released $18 \mathrm{mg}$ of exogenous melatonin; Ceva Animal France), and Group 3 ( $\mathrm{n}=20$ sheep, sheep maintained in artificial short-day conditions; 16D:8L). After separation of lambs on the $57^{\text {th }}$ day, the sheep were milked twice a day using an Alfa-Laval milking machine. Milk yields were measured every 10 days, and at that time, milk samples were collected from each group of sheep to determine the protein and casein contents. Feeding the sheep during the experiment was standardised. During the experiment, the sheep from groups 1 and 2 were maintained indoors with an option to use runs, and group 3 stayed indoors throughout the period that they were used for dairy production in a $20-\mathrm{m}^{2}$ room with artificial short-day conditions (16D:8L). The experiments demonstrated that the highest protein level was on the $60^{\text {th }}$ milking day (May) from the sheep maintained in the $16 \mathrm{D}: 8 \mathrm{~L}$ conditions $(6.87 \pm 0.01 \%$ protein), whereas milk from the sheep with melatonin implants had a protein content of $(5.86 \pm 0.02 \%)$, which was significantly lower $(\mathrm{P} \leq 0.01)$ (Table 5). Table 5 .

\begin{tabular}{ccccccc}
\hline \multirow{2}{*}{$\begin{array}{c}\text { Months of } \\
\text { milking used }\end{array}$} & \multicolumn{7}{c}{ Control group } & \multicolumn{2}{c}{ Exogenous melatonin } & \multicolumn{2}{c}{ 16D:8L group } \\
\cline { 2 - 7 } & $\bar{x}$ & $\mathrm{~S}(\mathrm{E})$ & $\bar{x}$ & $\mathrm{~S}(\mathrm{E})$ & $\bar{x}$ & $\mathrm{~S}(\mathrm{E})$ \\
April & 5.47 & 0.07 & 5.83 & 0.49 & 6.19 & 0.04 \\
May & $6.63^{\mathrm{B}}$ & 0.01 & $5.86^{\mathrm{A}}$ & 0.02 & $6.87^{\mathrm{B}}$ & 0.01 \\
June & $7.10^{\mathrm{b}}$ & 0.07 & $7.15^{\mathrm{b}}$ & 0.01 & $7.5^{\mathrm{a}}$ & 0.07 \\
July & $6.8^{\mathrm{B}}$ & 0.04 & $7.8^{\mathrm{A}}$ & 0.01 & $7.09^{\mathrm{B}}$ & 0.01 \\
\hline
\end{tabular}

A, B,- average levels marked with different letters vary significantly in drawn samples at $\mathrm{P} \leq 0.01$, $a, b$, - average levels marked with different letters vary significantly in drawn samples at $\mathrm{P} \leq 0.05$

Table 5. Effects of the diverse photoperiod and exogenous melatonin on the protein content (\%)

In June, the protein level in the milk of sheep in the 16D:8L conditions was markedly higher (P $\leq 0.05$ ), which was7.5 $\pm 0.07 \%$, whereas milk from sheep in the control group and with melatonin implants contained a lower level of protein $(7.1 \pm 0.07 \%$ and $7.15 \pm 0.01 \%$, respectively). In the fourth month of milking, the milk from sheep with melatonin implants had a protein content of $7.8 \pm 0.01 \%$, which was significantly higher ( $P \leq 0.01$ )than sheep without the implant, whereas the milk from sheep in the $16 \mathrm{D}: 8 \mathrm{~L}$ and control groups contained less protein $(7.09 \pm 0.01 \%$ and $6.8 \pm 0.04 \%$, respectively). Based on the results of the experiments, it was determined that the photoperiod represents an important factor that impacts the productivity of the animals. The protein content in the sheep with melatonin implants and sheep maintained in 16D:8L conditions increased from the first day of milking until the end of lactation. Upon analysing the changes in the casein content, it was determined that in the first month of milking (April), the lowest level of casein was identified in the milk of sheep raised under the $16 \mathrm{D}: 8 \mathrm{~L}$ conditions $(2.28 \pm 0.03 \%)$ and in the milk of sheep with melatonin implants $(2.32 \pm 0.03 \%)$, which was determined to be significant $(\mathrm{P} \leq 0.01)$. Table 6 


\begin{tabular}{ccccccc}
\hline \multirow{2}{*}{$\begin{array}{c}\text { Monthsof milking } \\
\text { used }\end{array}$} & \multicolumn{5}{c}{ Control group } & \multicolumn{2}{c}{ Exolish longwool sheep } \\
\cline { 2 - 7 } & $\bar{x}$ & $\mathrm{~S}(\mathrm{E})$ & $\bar{x}$ & $\mathrm{~S}(\mathrm{E})$ & $\bar{x}$ & $\mathrm{~S}(\mathrm{E})$ \\
April & $3.42^{\mathrm{A}}$ & 0.01 & $2.32^{\mathrm{B}}$ & 0.03 & $2.28^{\mathrm{B}}$ & 0.03 \\
May & $4.6^{\mathrm{a}}$ & 0.05 & $4.22^{\mathrm{b}}$ & 0.02 & $4.36^{\mathrm{b}}$ & 0.01 \\
June & $4.39^{\mathrm{B} . \mathrm{a}}$ & 0.02 & $5.35^{\mathrm{B} . \mathrm{b}}$ & 0.05 & $2.85^{\mathrm{A}}$ & 0.04 \\
July & $3.53^{\mathrm{A}}$ & 0.03 & $5.28^{\mathrm{B}}$ & 0.02 & $5.04^{\mathrm{B}}$ & 0.01 \\
\hline
\end{tabular}

A, B,- average levels marked with different letters vary significantly in drawn samples at $\mathrm{P} \leq 0.01$, $\mathrm{a}, \mathrm{b},-$ average levels marked with different letters vary significantly in drawn samples at $\mathrm{P} \leq 0.05$

Table 6. The effect of the diverse photoperiod and exogenous melatonin on the casein content (\%)

In subsequent months of lactation, the highest casein content was observed in the milk from sheep in the control group. However, in June, the casein content in the milk from sheep in the group with melatonin implants increased $(5.35 \pm 0.05 \%)$, whereas the casein content became significantly lower $(\mathrm{P} \leq 0.01)$ and approached $2.85 \pm 0.04 \%$ in sheep maintained in the $16 \mathrm{D}: 8 \mathrm{~L}$ conditions. In the last month of milking, the highest casein content $((\mathrm{P} \leq 0.01)$ was observed in the milk from sheep with melatonin implants $(5.28 \pm 0.02 \%)$, and the lowest casein levels were observed in milk from the control sheep $(3.53 \pm 0.03 \%)$. These results indicated that the protein content grew as lactation progressed in the control group, which was because of a change in the milk yields. Administration of exogenous melatonin and simulation of the short-day period exerted a significant influence on the protein and casein contents in sheep milk. Administration of exogenous melatonin in the period of lengthening days caused an increase in the protein content of sheep milk beginning in the $60^{\text {th }}$ day of lactation. Similarly, artificial simulation of the short-day conditions during the period of lengthening days resulted in an increase of the protein and casein contents in sheep milk. Casein is an important factor that functions in cheese curd formation; therefore, the high casein content in the milk of sheep with melatonin implants and sheep maintained in the 16D:8L artificial short-day conditions resulted in a higher processing efficiency.

\section{The effect of the day length and exogenous melatonin on the protein and casein contents in sheep milk produced at the time of the diverse photoperiod}

Given the intensified production of food with animal origins observed over the last few years as well as the enhanced nutritional awareness of consumers, the quality and particularly the nutritional and pro-health value of food [37] is a major criterion for choosing a food product. Therefore, the purpose of the present study was to determine the effects of day length and exogenous melatonin on the protein and casein contents in seasonally lactating sheep.

The experiments were performed on 60 Polish long-wool sheep mothers, which is a breed with a seasonal breeding cycle, and the sheep were 4 to 5 years of age and weighed $60 \pm 5 \mathrm{~kg}$. Synchronisation of the sheep estrous cycle was performed with gastagens using the 
Chronogest ${ }^{\circledR}$ method. Polyurethane foam saturated with $40 \mathrm{mg}$ of a cronolone preparation (Intervet; Holland) was inserted into the sheep vaginally for 14 days. When the foams were removed from the ewes, the ewes were administered 500 IU of PMSG. Estrous for the first group began on the $15^{\text {th }}$ of September, and for the second and third groups, on the $15^{\text {th }}$ of January. Ewes from the first group lambed in mid-February, and the lambs from the second and third groups lambed in mid-June: Group 1 ( $n=20$ sheep, sheep lambed in February that were maintained in natural day-length conditions and served as the control group), Group 2 ( $\mathrm{n}=20$ sheep, sheep lambed in June and maintained in natural day-length conditions), and Group 3 ( $\mathrm{n}=20$ sheep, sheep lambed in June with subcutaneous melatonin implants to introduce a short-day signal as early as possible and were maintained in long-day conditions). Six weeks before lambing, $18 \mathrm{mg}$ of exogenous melatonin (Ceva Animal; France) was introduced. Lambs were raised with mothers until the $56^{\text {th }}$ day of life before they were separated from their mothers, and the mothers were milked. After the $57^{\text {th }}$ day of lactation, the ewes were milked twice-a-day using an Alfa-Laval milking machine. Milk yields were measured every 10 days and collective milk samples were drawn from each group of sheep to determine the protein content. Feeding the sheep during the experiment was standardised. During the experiment, the sheep were raised indoors with an option to use runs. The conducted experiments demonstrated that shifting lactation to the period of shortening days and administration of exogenous melatonin caused an increase in the protein content. In the first month of significant milking ( $\mathrm{P} \leq 0.05)$, the highest level of protein was observed in the milk of the sheep that lambed in June $(6.7 \pm 0.8 \%)$ and in the milk of mothers with subcutaneous melatonin implants (6.3 $\pm 0.8 \%$; shown in Table 7$)$.

\begin{tabular}{ccccccc}
\hline \multirow{2}{*}{$\begin{array}{c}\text { Months of } \\
\text { milking used }\end{array}$} & $\begin{array}{c}\text { Sheep milking used in } \\
\text { long days }\end{array}$ & $\begin{array}{c}\text { Polish longwool sheep } \\
\text { Sheep milking used in } \\
\text { short days }\end{array}$ & $\begin{array}{c}\text { Sheep with exogenous } \\
\text { melatonin }\end{array}$ \\
\cline { 2 - 7 } & $\bar{x}$ & $\mathrm{~S}(\mathrm{E})$ & $\bar{x}$ & $\mathrm{~S}(\mathrm{E})$ & $\bar{x}$ & $\mathrm{~S}(\mathrm{E})$ \\
April & $5.42^{\mathrm{a}}$ & 0.7 & - & - & - & - \\
May & $5.7^{\mathrm{a}}$ & 0.5 & - & - & - & - \\
June & $5.49^{\mathrm{A}}$ & 0.6 & - & - & - & - \\
July & 6.2 & 0.8 & - & - & - & - \\
August & 6.8 & 0.8 & $6.7^{\mathrm{b}}$ & 0.8 & $6.3^{\mathrm{b}}$ & 0.8 \\
September & - & - & $7.49^{\mathrm{b}}$ & 0.8 & $7.19^{\mathrm{b}}$ & 0.9 \\
October & - & - & $8.05^{\mathrm{B}}$ & 0.9 & $7.6^{\mathrm{B}}$ & 0.9 \\
\hline
\end{tabular}

A, B,- average levels marked with different letters vary significantly in drawn samples at $\mathrm{P} \leq 0.01$,

$a, b$, - average levels marked with different letters vary significantly in drawn samples at $P \leq 0.0$

Table 7. The effect of the day length and exogenous melatonin on the protein content (\%)

In the second month of significant milking $(\mathrm{P} \leq 0.05)$, the highest level of protein was recorded in the milk of the sheep that lambed in June $(7.49 \pm 0.9 \%)$ and in the milk of sheep with melatonin implants $(7.19 \pm 0.9 \%)$. At the same time, the lowest protein content was identified in the milk of sheep entering lactation in the long-day period $(5.7 \pm 0.5 \%)$. In the 
third sample $(\mathrm{P} \leq 0.01)$, the highest level of protein was detected in the milk of the sheep that lambed in June $(8.05 \pm 0.9 \%)$ and in the milk of sheep exposed to exogenous melatonin $(7.19 \% \pm 0.9 \%)$. It is important to note that in sheep from the control group, the highest protein content was observed in the last month of lactation $(6.8 \pm 0.8 \%)$, whereas a comparable level of protein in the group of sheep milked in the period of shortening days and with melatonin implants was identified in the first month of milking. The identified changes in the protein content suggest that the milk of sheep entering lactation in the period of shortening days and exposed to the effects of exogenous melatonin can differ with respect to the casein content compared to the milk from sheep in the control group. Table 8.

\begin{tabular}{ccccccc}
\hline \multirow{2}{*}{$\begin{array}{c}\text { Months of } \\
\text { milking used }\end{array}$} & $\begin{array}{c}\text { Sheep milking used in } \\
\text { long days }\end{array}$ & $\begin{array}{c}\text { Polish longwool sheep } \\
\text { Sheep milking used in } \\
\text { short days }\end{array}$ & $\begin{array}{c}\text { Sheep with exogenous } \\
\text { melatonin }\end{array}$ \\
\cline { 2 - 7 } & $\bar{x}$ & $\mathrm{~S}(\mathrm{E})$ & $\bar{x}$ & $\mathrm{~S}(\mathrm{E})$ & $\bar{x}$ & $\mathrm{~S}(\mathrm{E})$ \\
April & $3.9^{\mathrm{a}}$ & 0.01 & - & - & - & - \\
May & $4.31^{\mathrm{a}}$ & 0.02 & - & - & - & - \\
June & $4.10 \mathrm{a}$ & 0.03 & - & - & - & - \\
July & 4.63 & 0.03 & - & - & - & - \\
August & 5.06 & 0.04 & $5.2^{\mathrm{b}}$ & 0.04 & $4.87^{\mathrm{b}}$ & 0.02 \\
September & - & - & $5.73^{\mathrm{b}}$ & 0.03 & $5.63^{\mathrm{b}}$ & 0.03 \\
October & - & - & 4.95 & 0.02 & $5.59^{\mathrm{b}}$ & 0.02 \\
\hline
\end{tabular}

$\mathrm{a}, \mathrm{b}$, - average levels marked with different letters vary significantly in drawn samples at $\mathrm{P} \leq 0.05$

Table 8. The effect of the day length and exogenous melatonin on the casein content (\%)

In sheep milked during the long-day period, the casein content increased as lactation progressed and milk yields dropped. The lowest level of casein was observed in the first month of milking $(3.9 \pm 0.1 \%)$, whereas the highest casein content was observed in milk obtained during the last month of milking $(5.06 \pm 0.4 \%)$. The shift of lactation to the period of shortening days resulted in an increase of the casein content in the examined milk in the first month of milking (5.2 $\pm 0.4 \%)$. Administration of exogenous melatonin 6 weeks before lambing also contributed to a change in the casein content of the milk. In the first month of milking, the milk of sheep exposed to exogenous melatonin contained $4.87 \pm 0.2 \%$ of casein, whereas on the $90^{\text {th }}$ day of milking, the milk contained as much as $5.59 \pm 0.2 \%$ casein. Thus, the milk from sheep milked in the short-day period and exposed to the effects of exogenous melatonin contained significantly more casein than milk from sheep milked in the long-day period. It is important to note that the milk from sheep lambed in June (groups 2 and 3) exhibited a higher casein content that corresponded with the casein content observed in the final phase of lactation from sheep milked under the long-day period. While analysing the total protein and casein contents in sheep milk and taking into account the whole milking period, it was shown that the protein and casein contents in sheep milk grew significantly by applying exogenous melatonin (Table 9). Similarly, the milk of sheep milked in the short- 
day period had a higher level of protein and casein than milk from sheep that were milked in the long-day period. Table 9.

\begin{tabular}{|c|c|c|c|c|c|c|}
\hline \multirow{3}{*}{ Parameters } & \multicolumn{6}{|c|}{ Polish longwool sheep } \\
\hline & \multicolumn{2}{|c|}{$\begin{array}{c}\text { Sheep milking used in } \\
\text { long days }\end{array}$} & \multicolumn{2}{|c|}{$\begin{array}{c}\text { Sheep milking used in } \\
\text { short days }\end{array}$} & \multicolumn{2}{|c|}{$\begin{array}{c}\text { Sheep with exogenous } \\
\text { melatonin }\end{array}$} \\
\hline & $\bar{x}$ & $S(E)$ & $\bar{x}$ & $S(E)$ & $\bar{x}$ & $S(E)$ \\
\hline Protein $(\%)$ & $5.92^{\mathrm{AB}}$ & 0.49 & $7.30^{\mathrm{A}}$ & 0.64 & $7.43^{\mathrm{B}}$ & 0.71 \\
\hline Casein $(\%)$ & $1.15^{\mathrm{ab}}$ & 0.04 & $0.85^{\mathrm{ab}}$ & 0.13 & $1.72^{\mathrm{b}}$ & 0.19 \\
\hline
\end{tabular}

A, B,- average levels marked with different letters vary significantly in drawn samples at $\mathrm{P} \leq 0.01$ $a, b$, - average levels marked with different letters vary significantly in drawn samples at $\mathrm{P} \leq 0.05$

Table 9. The effect of the day length and exogenous melatonin on the total protein and casein content in the period in which sheep are used for dairy production

Casein is a protein that plays a fundamental role in cheese production; its high content in sheep milk signifies a high production efficiency of this material. In milk from the examined groups of sheep, a significantly higher level of casein was observed in the group of sheep that lambed in June and is correlated with an increase in total nitrogen compounds, which had a significantly higher concentration in the milk from this group of sheep.

\section{Conclusions}

The increase of interest in nutritional and pro-health values of food has resulted in more attention to components that are of paramount importance to the health of people. In general, consumers pay attention to the quality of consumable products while searching for products whose composition is as close as possible to the "natural" product (i.e. the least processed foods). The chemical composition of sheep milk indicates a high technological value of the milk from this animal breed and its fitness for processing into cheese. The studies performed by Ciuryk et al. (1999) and Molik et al. (2006 and 2007) showed that the milk yields of sheep with strong seasonal breeding characteristics depend on the lambing time of the ewes. It was also concluded that shifting the lambing time to the spring and summer months has a negative impact on the duration of lactation and amount of milk obtained as well as its chemical composition, which suggested that, aside from genetic and environmentally related factors, an important role in the process of entering and maintaining lactation is assigned to the day length, which is a factor that modulates the level of melatonin and prolactin. Thus, only prolactin secretion changes in lactating sheep influences the amount of milk produced and the synthesis of milk proteins. In natural conditions, the maximum concentration of prolactin in sheep blood is observed in the longday period as opposed to the time when the level of melatonin drops. The lowest concentration of prolactin is recorded during the short days when the level of melatonin is the highest. Shortening of the day length or prolonged administration of exogenous 
melatonin during the period of physiologically increased concentrations of prolactin causes a reduction in the secretion of this hormone. Changes in the secretion of prolactin during the lactation period in sheep undoubtedly have an influence on the amount of milk produced and its chemical composition [38]. The conducted studies revealed that administering exogenous melatonin and modulation of the day length had a significant influence on the protein and casein contents in sheep milk. However, shifting the lactation time to the period of shortening days and applying exogenous melatonin caused an increase in the protein content within the first month of milking. The protein content in the milk of sheep milked during the period of shortening days and exposed to the effects of exogenous melatonin was adequate in the last stage of lactation compared to sheep milked during the long-day period. The performed studies demonstrate that day length and melatonin are factors that modulate the protein content in the milk of seasonally breeding sheep.

\section{Author details}

Edyta Molik* and Dorota Zięba

Department of Swine and Small Ruminant Breeding, Biotechnology and Genomic Laboratory, Agricultural University in Krakow, Poland,

Genowefa Bonczar and Aneta Żebrowska

Department of Animal Product Processing, Agricultural University in Krakow, Poland,

Tomasz Misztal

Department of Endocrinology, The Kielanowski Institute of Animal Physiology and Nutrition, Polish Academy of Sciences, Poland

\section{Acknowledgement}

This research was supported by projects MNiSZW NN311245033 and DS/KHiOK/3242/2010.

\section{References}

[1] Mubois JL, Leorii J (1989) Peptides du lait a activite biologique. Lait. 69: 245-835.

[2] Bonczar G, Paciorek A (1999) Właściwości mleka owczego. Zesz. Nauk. AR. Kraków. 360: 37-48.

[3] Ciuryk S, Molik E, Bonczar G (1999) Wydajność i skład chemiczny mleka plennej owcy olkuskiej, długowełnistej i mieszańców po trykach charollais, Zesz. Nauk. PTZ. 43 : 73 79. In Polish.

[4] Ramos M, Juarez M (2003) Sheep milk, Encyclopedia of Dairy Sciences. In: editor Roginski H, Fuquay JW, Fox PF. pp 2539-2545.

\footnotetext{
${ }^{*}$ Corresponding Author
} 
[5] Anifantakis E M (1986) Comparison of the physico-chemical properties of ewe's and cow's milk, FIL. Doc. 202: 42-53.

[6] Molik E, Ciuryk S, Misztal T, Romanowicz K, Wierzchos E (2004) Effect of climatic conditions on milk yield of polish longwool sheep lambing on different dates. Scien. Messeng. Lviv. 6: 58-62.

[7] Bonczar G (1989) Zmiany składu chemicznego i cech fizycznych mleka owczego w zależności od stanu zdrowotnego wymienia. Zesz. Nauk. AR Kraków. 133: 2-133. In Polish.

[8] Novotna L, Kuchtik J, Dobes I, Sustova K, Zajicova P (2007) Effect of somatic cell count on ewe's milk composition, its propierties and quality of rennet curd. Acta. Universita. Brunensis. 55: 59-64.

[9] Szczepanik A, Libudzisz Z (2001) Przydatność technologiczna mleka koziego Przem. Spoż. 2: 35 - 36. In Polish.

[10] Wszołek M, Tamime AY, Muir DD, Barclay MNI (2001) Properties of Kefir made in Scotland and Poland using bovine, caprine and ovine milk with different starter cultures. Lebensm.-Wiss. u.-Technol. 34: 251 - 261.

[11] Bonczar, G (1990) The content of nitric substances in ewe's milk in relation to age, period of lactation, and health of udder. Zbornik Bioteh. Univer. EK v Ljubljani. 15: 549556.

[12] Park YW, Juarez M, Ramos M, Haenlein GFW (2007) Physico-chemical characteristics of goat and sheep milk. Small. Rumin. Res. 68: 88-113.

[13] Haenlein GFW (1997) Nutritional value of dairy products of ewes and goats milk. Sheep Dairy. News. 13 (1): 10-16.

[14] Kędzior W (2005) Owcze produkty spożywcze. Aspekty Towaroznawcze. Warszawa: PWE. 250 p. In Polish.

[15] Haenlein GFW (2001) Past, Present, and Future Perspectives of Small Ruminant Dairy Research. J. Dairy Sci. 84: 2097 - 2115.

[16] Recio I, Visser S (2000) Antibacterial and binding characteristics of bovine, ovine and caprine lactoferrins: a comparative study. Inter. Dairy Jour. 10: 597-605

[17] Ziajka S (2008) Mleczarstwo - Volume 1. Olsztyn. UWM.380 p. In Polish.

[18] Clare DA, Swaisgood HE (2000) Bioactive Milk Peptides -A Prospectus. J. Dairy. Sci. 83: 1187 - 1195.

[19] Lahov E, Regelson W (1996) Antibacterial and immunostimulating casein-derived substances from milk: casecidin, isracidin peptides. Food Chem. Toxicol. 34: 131 - 145.

[20] Bonczar G (2001) Znaczenie mleka owczego w żywieniu człowieka. Przeg. Mlecz. 3: 125-128. In Polish.

[21] Ważna E (1997) Wartość mleka owczego. Por. Gos. 12. 1- 26. In Polish.

[22] Borys B, Pisulewski PM (2001) Jakość oraz możliwości kształtowania prozdrowotnych właściwości spożywczych produktów owczarskich. Rocz. Nauk. Zoot. 11: 67-86. In Polish. 
[23] Rowan W (1925). Relation of light to bird migration and developmental changes. Nature. 115: 494-495.

[24] Reksen O, Tverdal A, Landsverk K, Kommisrud E, Boe KE, Ropstad E (1999) Effects of photointensity and photoperiod on milk yield and reproductive performance of Norwegian Red Catlle. J. Dairy Sci. 82: 810-816.

[25] Misztal T, Romanowicz K, Barcikowski B (1996) Seasonal changes of melatonin secretion in relation to the reproductive cycle in sheep. J. Anim Feed Sci. 56: 35-48.

[26] Reiter RJ (1988) Neuroendocrinology of melatonin. In: Melatonin Clinical Perspectives. editors: Miles A, Philbrick DRS, Thomson C, Oxford: Oxford University Press. pp 1-42.

[27] Reiter RJ (1991a) Melatonin: that ubiquitously acting pineal hormone. News. Physiol. Sci. 6: 223-227.

[28] Reiter RJ (1991b) Pineal melatonin; cell biology of its synthesis and of physiology interactions. Endocr. Rev. 12: 151-180

[29] Arendt J (1993) Biological rythms. The mammalian pineal gland and its control of hypohalamic activity. Prog. Brain Res. 41: 149-174.

[30] Peaker M, Neville, MC (1991) Hormons in milk: chemical signals to the offspring's'. J. Endocrinol. 131: 1-3

[31] Molik E, Murawski M, Bonczar G, Wierzchos E (2008) Effect of genotype on yield and chemical composition of sheep's milk. Anim. Sci. Paper. Rep. 26: 211-218.

[32] Robinson JJS, Wigzell RP, Aitken JM, Wallace S, Ireland, Robertson IS (1992) Daily oral administration of melatonin from March on wards advances by 4 months the breeding season of ewes maintained under the ambient photoperiod at $57^{0} \mathrm{~N}^{\prime}$. Anim. Reprod. Sci. 27: $141-160$

[33] Misztal T, Romanowicz K, Barcikowski B (1999) Melatonin modulation of the daily prolactin secretion in intact and ovariectomized ewes, relation to phase of the estrous cycle and to the presence of estradiol. Neuroendocrinology. 69: 105-112.

[34] Molik E, Misztal T, Romanowicz K, Wierzchoś E (2006) The Influence of length day on melatonin secretion during lactation in asesonal sheep. Arch. Tierz. 49: 359-364.

[35] Molik E, Misztal T, Romanowicz K, Wierzchoś E (2007) Dependence of the lactation duration and efficiency on the season of lambing in relation to the prolactin and melatonin secretion in ewes. Liv. Sci. 107: 220-226

[36] Molik E, Misztal T, Romanowicz K, Zięba D, Wierzchoś E (2009) Changes in growth hormone and prolactin secretion in ewes used for milk under different photoperiodic conditions. Bull. Vet. Inst. Pulawy. 53: 389-393

[37] Zebrowska A, Bonczar G, Molik E (2009) Właściwości prozdrowotne mlecznych napojów fermentowanych. Przeg. Hod. 8: 24-26.

[38] Molik E, Bonczar G, Żebrowska, Misztal T, Pustkowiak H, Zieba D (2011) Effect of day length and exogenous melatonin on chemical composition of sheep milk. Archiv. Tierz. 54: $177-187$ 
[39] Fox PF (2003) Milk. Encyclopedia of Dairy Sciences. London: Elsevier Science. pp.100

[40] Jandal JM (1996) Comparative aspects of goat and sheep milk. Small. Rum. Res. 22: 177 -185 .

[41] Obrusiewicz T (1994) Mleczarstwo. Part 1. WSiP. Warszawa. pp 250. In Polish. 